\title{
Pemberian Scaffolding dalam Bahan Belajar Berbasis Masalah untuk Meningkatkan Kemampuan Berpikir Tingkat Tinggi Siswa
}

\author{
Rini Wahyu Fajriani ${ }^{1}$, M. Naswir ${ }^{2}$, Harizon ${ }^{3}$ \\ Program Studi Magister Pendidikan Kimia, Universitas Jambi, Jambi, Indonesia \\ e-mail: riniwfajr@gmail.com
}

DOI: https://doi.org/10.33369/pendipa.5.1.108-114

\begin{abstract}
[Providing Scaffolding in problem based learning materials to improve students' higher-order thinking skills] The types of problems in teaching students vary, ranging from simple to complex. In solving these types of problems, students cannot do it themselves but need to be taught by the teacher. Efforts that can be made by the teacher to achieve this are by assisting (scaffolding). Scaffolding is a support given by teachers to students to solve problems in the learning process. In addition to scaffolding, in solving complex types of problems, optimization of higher-order thinking skills is also needed in increasing the success of the learning process. No exception to studying chemistry. With the provision of scaffolding in chemistry learning materials, it is hoped that the abstract concept of chemical material will be easier for students to understand. This study is qualitative research using survey methods through questionnaires and in-depth interviews from three different schools in Jambi. The data obtained were then analyzed descriptively. From the study results, it was found that students were not used to solving complex types of problems as well as teachers who were not used to organizing the ideal scaffolding form used in learning materials in chemistry learning. Therefore, it is important and needs to be further developed this learning materials.
\end{abstract}

Keywords: Scaffolding; Learning Materials; Learning in Chemistry; Higher Order Thinking Skills.

\begin{abstract}
ABSTRAK
Jenis masalah dalam membelajarkan siswa beraneka ragam, mulai dari yang sederhana hingga yang kompleks. Dalam memecahkan jenis masalah, siswa tidak dapat melakukannya sendiri melainkan perlu dilatihajarkan oleh guru. Upaya yang dapat dilakukan guru agar hal ini tercapai yakni dengan memberikan bantuan (scaffolding). Scaffolding merupakan bantuan yang diberikan guru kepada siswa untuk memecahkan permasalahan dalam proses pembelajaran. Selain Scaffolding, dalam memecahkan jenis masalah kompleks, pengoptimalan kemampuan berpikir tingkat tinggi juga diperlukan dalam meningkatkan keberhasilan proses pembelajaran. Tidak terkecuali pada pembelajaran kimia. Dengan diberikannya scaffolding dalam bahan belajar kimia, diharapkan konsep materi kimia yang bersifat abstrak akan lebih mudah dipahami oleh siswa. Penelitian ini merupakan penelitian kualitatif dengan menggunakan metode survey melalui kuisioner dan wawancara bersama guru dan siswa yang berasal dari tiga sekolah berbeda di Jambi. data yang didapatkan kemudian dianalisis secara deskriptif. Dari hasil penelitian ditemukan bahwa siswa belum terbiasa memecahkan jenis masalah kompleks begitu juga dengan guru yang belum terbiasa mengorganisasikan bentuk scaffolding yang ideal digunakan dalam bahan belajar pada pembelajaran kimia. Maka dari itu, penting dan perlu dilakukan pengembangan bahan belajar berbasis masalah yang dilengkapi scaffolding guna meningkatkan kemampuan berpikir tingkat tinggi siswa.
\end{abstract}

Kata kunci: Scaffolding; Bahan belajar Berbasis Masalah; Kemampuan Berpikir Tingkat Tinggi. 


\section{PENDAHULUAN}

\section{Latar Belakang Masalah}

Proses pembelajaran pada dasarnya memiliki tujuan utama untuk melahirkan siswa yang tidak sekedar memahami suatu masalah dan penyebabnya, melainkan membentuk karakter "problem solver' yang memiliki kemampuan dan keterampilan mumpuni agar dapat memecahkan masalah disekolah maupun masalah yang dihadapi kelak di masyarakat. Membentuk sosok karakter 'problem solver' dalam diri siswa dapat dilatih ajarkan melalui aktivitas proses pembelajaran. Aktivitas dalam proses pembelajaran yang ideal menurut teori yakni tidak hanya menekankan pada perolehan pengetahuan seluas-luasnya akan tetapi menekankan pada bagaimana menggunakan pengetahuan tersebut untuk menghadapi situasi baru yang tidak terduga atau memecahkan masalah spesifik yang berkaitan dengan apa yang dipelajari. Tidak terkecuali pada proses pembelajaran kimia.

Dalam pembelajaran kimia, ada banyak konsep kimia bersifat abstrak yang harus diserap siswa dalam waktu terbatas. Hal ini menjadikan kimia sebagai salah satu mata pelajaran yang sulit, akibatnya banyak siswa yang gagal mempelajari kimia seutuhnya dikarenakan siswa cenderung belajar dengan menghafal daripada membangun sendiri pemahamannya mengenai konsep kimia. Konsep kimia tidak hanya bersifat abstrak, melainkan juga kompleks. Seringkali siswa kesulitan menghubungkan antara konsep kimia dan implikasinya dalam kehidupan seharihari. Oleh karenanya guru disekolah terkadang memberikan bahan belajar berupa Lembar Diskusi Siswa(LDS), modul maupun Lembar Kerja Peserta Didik (LKPD) kepada siswa berbasis masalah kontekstual yang dapat membantu siswa mengatasi kesulitan tersebut. Namun, dikarenakan keterbatasan guru dalam menyusun bahan belajar yang sesuai dengan karakteristik siswa, tidak jarang guru menggunakan bahan belajar yang sama berulang dengan jenis masalah yang dibahas bersifat sederhana belum kompleks. Hal ini mengakibatkan siswa hanya terlatih untuk memecahkan masalah sederhana saja, tidak dengan masalah yang bersifat kompleks.

Rumusan Masalah
Adapun rumusan masalah pada penelitian ini yakni seberapa pentingnya pemberian scaffolding dalam bahan belajar berbasis masalah untuk meningkatkan kemampuan berpikir tingkat tinggi siswa?

\section{Kajian Teoritik}

Wena (2011) mengemukakan bahwa pada hakikatnya memecahkan masalah berarti melakukan langkah-langkah prosedural sistematis sesuai dengan jenis masalah yang dipecahkan. Menurut Jonassen (2011) terdapat beberapa jenis masalah yang dapat membantu guru dalam menciptakan lingkungan belajar yang efektif untuk menstimulasi siswa yang bertujuan untuk menentukan bagaimana cara memecahkan masalah secara efektif. Jenis masalah tersebut diantaranya jenis masalah story, decision making, troubleshooting, strategic performance, policy analysis, dan design. Akan tetapi, jenis masalah seperti ini tidak hanya membutuhkan kemampuan berpikir analisis seperti biasanya melainkan membutuhkan kemampuan berpikir tingkat tinggi. Higher Order Thinking Skills (HOTS) atau kemampuan berpikir tingkat tinggi (Brookhart, 2010) meliputi beberapa aspek, yaitu: 1) Analisis, evaluasi, kreasi, 2) Penalaran yang logis atau logika beralasan (logical reasoning), 3) Keputusan dan berpikir kritis, 4) Pemecahan masalah, 5) Kreativitas dan berpikir Kreatif.

Untuk melatih siswa agar dapat memecahkan berbagai jenis masalah dari yang sederhana hingga kompleks maka guru dapat memberikan bantuan. Bantuan tersebut berupa scaffolding yang sedikit demi sedikit berkurang pada tiap tahapnya selama proses pembelajaran. Scaffolding pada dasarnya merupakan bentuk bantuan yang diberikan guru dalam aktivitas belajar dikelas. Scaffolding tanpa disadari sudah ada dan diberikan guru setiap harinya selama proses pembelajaran berlangsung, namun, bentuk Scaffolding yang diberikan tersebut belum diorganisasikan dengan baik sehingga dalam penggunaanya tidak memaksimalkan capaian tujuan pembelajaran. Scaffolding dapat berupa petunjuk, dorongan, peringatan, menguraikan masalah ke dalam langkah-langkah pemecahan, memberikan contoh dan lain sebagainya. Dalam aktivitas belajar, Tiaradipa (2020) menyatakan bahwa scaffolding dapat dikatakan sebagai penghubung antara pengatahuan awal yang telah 
dimiliki dengan sesuatu yang baru atau yang akan dikuasai/diketahui siswa. Lebih lanjut Tiaradipa (2020) melalui hasil penelitiannya mengemukakan bahwa peran scaffolding sangat membantu guru memaksimalkan pencapaian tujuan pembelajaran dan kemampuan berpikir serta kemampuan proses sains yang dimiliki oleh siswa. Sejalan dengan Tiaradipa, Puspitaningsih dkk. (2018) dalam penelitiannya menyatakan bahwa scaffolding baik prosedural maupun konseptual yang diberikan guru melalui model pembelajaran PBL mampu meningkatkan kemampuan berpikir tingkat tinggi siswa sebesar 42,5\% ditinjau dari kemampuan tinggi dan rendah.

\section{Tujuan Penelitian}

Dari penjelasan dan penelitian yang relevan tersebut, maka pemberian scaffolding dalam bahan belajar bertujuan untuk memaksimalkan upaya guru dalam meningkatkan kemampuan berpikir tingkat tinggi siswa perlu dilakukan melalui penelitian pengembangan maupun eksperimentasi guna mengetahui lebih dalam implikasi scaffolding dan jenis masalah dalam pembelajaran.

\section{METODE PENELITIAN}

\section{Rancangan Penelitian}

Penelitian ini merupakan penelitian kualitatif yang menunjukkan pentingnya pemberian scaffolding dalam bahan belajar berbasis jenis masalah yang spesifik guna meningkatkan kemampuan berpikir tingkat tinggi peserta didik.

\section{Teknik Pengumpulan data}

Metode yang digunakan yakni survey melalui pengisian kuisioner oleh siswa, wawancara mendalam bersama guru, observasi langsung kondisi lapangan serta studi literatur maupun penelitian terkait.

Teknik Analisis Data
Data yang didapat dari hasil kuisioner wawancara, serta observaasi langsung dilapangan kemudian dianalisis menggunakan teknik analisis Miles dan Huberman sebelum akhirnya didapatkan kesimpulan akhir.

Waktu dan Lokasi Penelitian

Penelitian ini dilakukan di tiga sekolah berbeda di Jambi yakni SMA Islam Al- Falah, SMAN Titian Teras Jambi dan SMAN 11 Kota Jambi. yang dilaksanakan pada semester ganjil tahun pelajaran 2020-2021.

\section{HASIL DAN PEMBAHASAN}

Penelitian ini merupakan penelitian deskriptif kualitatif dengan metode survey melalui pengisian kuisioner. Selain menggunakan kuisioner untuk mengetahui pendapat siswa, juga dilakukan wawancara dan observasi langsung untuk mengetahui kondisi tiga sekolah yang menjadi sampel penelitian. Kemudian hasil yang didapatkan dianalisis dengan melakukan triangulasi data untuk kemudian disimpulkan.

\section{Survey}

Survey yang dilakukan dalam penelitian ini dilaksanakan dengan kuisioner yang berikan menggunakan google form kepada siswa kelas XI MIPA di tiga sekolah berbeda yakni SMA Islam Al Falah, SMA N Titian Teras dan SMA N 11 Kota Jambi. Dari hasil survey berupa kuisioner, dua hal penting yang dapat ditelaah yakni pendapat siswa mengenai materi kimia dan kebutuhan siswa akan bahan belajar yang dapat melatih siswa memecahkan masalah. Dengan bahan belajar siswa tidak lagi mengandalkan buku paket dan penejlasan guru dari guru saja melainkan dapat secara mandiri belajar. Hal pertama yang ingin diketahui yakni kesulitan yang dihadapi dalam mempelajari materi kimia. Berikut grafik hasil survey yang didapatkan: 


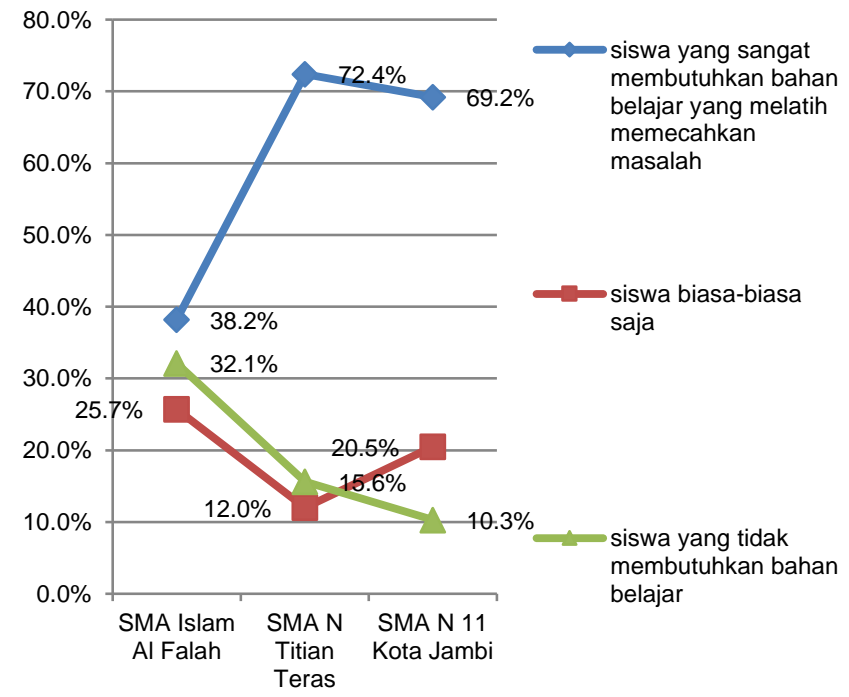

Gambar 1. Grafik hasil survey kuisioner siswa mengenai mata pelajaran kimia

Dari gambar diatas terlihat bahwa ada lebih banyak siswa yang mengalami kesulitan dalam mempelajari kimia yakni berturut-turut $45 \%, 27 \%$ dan $64 \%$, siswa yang biasa-biasa saja berturut-turut $26 \%, 53 \%$ dan $19 \%$, sedangkan siswa yang tidak mengalami kesulitan yakni berturut-turut $29 \%$, 20\% dan $17 \%$.

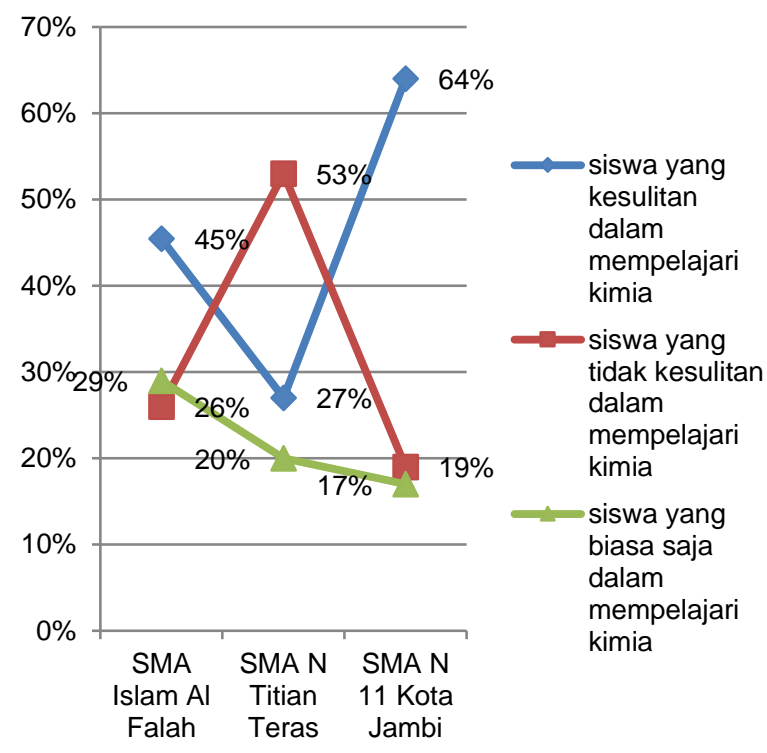

Gambar 2. Grafik hasil survey kuisioner siswa mengenai kebutuhan bahan belajar berbasis masalah

Sedangkan pada gambar diatas merupakan pendapat siswa mengenai bahan belajar berbasis masalah. Dari gambar terlihat jelas bahwa siswa yang sangat membutuhkan bahan belajar yakni berturut-turut $38,2 \%, 72,4 \%$ dan $69,2 \%$. Sangat membutuhkan bahan belajar disini bukan berarti bahwa siswa tidak mampu dari segi kognitif, melainkan siswa menginginkan bahan belajar yang berbeda untuk dipelajari yakni bahan belajar yang berbasis masalah.

\section{Wawancara}

Sama halnya dengan siswa, guru juga melalui hasil wawancara diketahui bahwa guru mengalami kesulitan dalam meningkatkan pemahaman siswa pada materi kimia tertentu yang bersifat abstrak, apalagi kemampuan berpikir tingkat tingginya. dari hasil wawancara diketahui kurang dari $50 \%$ siswa masih belum mencapai KKM, serta soal evaluasi siswa hanya terbatas pada $\mathrm{C}_{4}$ belum mencapai $\mathrm{C}_{6}$ yang dituntutkan ke pada siswa saat ini.

Selain itu, alokasi waktu yang terbatas serta beban mengajar guru yang berat menyebabkan guru hanya memberikan bahan belajar berupa LDS, powerpoint, maupun LKS/LKPD komersil yang seringkali tidak sesuai dengan kondisi dan karakteristik siswa. Begitu juga dengan scaffolding yang diberikan guru belum dapat memaksimalkan pencapaian tujuan pembelajaran maupun kemampuan siswa.

Menurut Tindangen (2018) pembelajaran dengan bantuan bahan belajar berupa LKPD dapat meningkatkan kemampuan berpikir tingkat tinggi siswa untuk belajar memecahkan masalah berdasarkan fenomena yang terjadi disekitar. Kemampuan berpikir tingkat tinggi terdiri dari tiga kategori, yaitu kemampuan berpikir tingkat tinggi sebagai transfer, kemampuan berpikir tingkat tinggi sebagai berpikir kritis dan kemampuan berpikir tingkat tinggi sebagai pemecahan masalah. Kemampuan berpikir tingkat tinggi sebagai transfer didefinisikan sebagai keterampilan untuk mengaplikasikan pengetahuan dan keterampilan yang sudah dikembangkan dalam pembelajaran pada konteks yang baru. Kemampuan berpikir tingkat tinggi 
sebagai berpikir kritis didefinisikan sebagai keterampilan memberikan penilaian yang bijak dan mengkritisi sesuatu menggunakan alasan logis dan ilmiah. Kemampuan berpikir tingkat tinggi sebagai pemecahan masalah didefinisikan sebagai keterampilan mengidentifikasi masalah dan menyelesaikan masalah menggunakan strategi yang nonautomatic, dengan kemampuan ini, peserta didik akan mampu menyelesaikan permasalahan mereka sendiri dan bekerja dengan lebih efektif (Nugroho, 2018).

Menurut Sani (2019) seseorang yang memiliki keterampilan berpikir akan dapat menerapkan informasi baru atau pengetahuannya untuk memanipulasi informasi dalam upaya menemukan solusi maupun jawaban yang mungkin untuk sebuah permasalahan yanng baru. Jika permasalahan yang dihadapi tidak dapat diselesaikan dengan cara yang biasa dilakukan dan persoalan cukup kompleks, maka dibutuhkan keterampilan berpikir tingkat tinggi untuk dapat menyelesaikan masalah tersebut.

Pada hakikatnya, kemampuan berpikir tingkat tinggi merupakan kemampuan yang harus dimiliki oleh siswa. Melalui kemmapuan berpikir ini siswa akan terlatih untuk memecahkan masalah yang dihadapi kimia maupun dimasa yang akan datang (Widiawati, 2018). Pada saat ini, siswa akan menghadapi berbagai jenis masalah yang tidak biasa, mulai dari masalah yang tidak pasti dan dilema. Namun, jika siswa berhasil menguasai kemampuan berpikir tingkat tinggi, siswa akan mampu menjadi lebih kritis, logis, reflektif, metakognitif dan kreatif. Oleh sebab itu, untuk dapat mencapai hal tersebut maka siswa perlu dilibatkan dalam situasi dan latihan terkait penyelesaian masalah yang tidak hanya mengingat dan menghafal serta menirukannya lagi.

Akan tetapi pada kenyataannya memecahkan masalah merupakan aktivitas yang kompleks yang dipengaruhi berbagai macam faktor yakni tingkat kematangan kognitif, motivasi, serta tingkah laku(karakter). Oleh karena faktor tersebut, maka diperlukan pengembangan kemampuan memecahkan masalah dengan merancang bantuan/scaffolding. Scaffolding berbeda dari jenis bantuan biasa, scaffolding merupakan jenis bantuan yang dapat membantu siswa secara mandiri untuk menyelesaikan permasalahan kompleks yang dihadapinya dalam aktivitas belajar (Belland, 2017). Yuriev (2017) mengemukakan bahwa bantuan yang dapat diberikan kepada siswa dalam memecahkan masalah dapat berupa alur/bagan alir atau goldilock. scaffolding berbentuk goldilock inilah yang akan membantu siswa untuk menghadapi kesulitan prosedural yang dihadapi dalam menyelesaikan permasalahan.

Sejalan dengan Yuriev, Haryati (2020) melalui penelitiannya mengemukakan bahwa peran scaffolding sangat membantu guru dalam meningkatkan kemampuan proses sains siswa. Dengan adanya scaffolding berupa alur bersamaan dengan bahan belajar berupa LKPD efektif digunakan baik oleh guru maupun siswapada materi larutan penyangga yang dilaksanakan sesuai dengan model pembelajaran project based learning( $\mathrm{PjBL})$. Lain halnya dengan Haryati, Puspitaningsih (2018) melalui penelitiannya mengenai pengaruh PBL dengan scaffolding prosedural terhadap kemampuan berpikir tingkat tinggi, diketahui bahwa scaffolding prosedural membantu siswa menggunakan aktivitas belajar dikelas untuk menyelesaikan tugas, mencapai tujuan serta menyelesaikan masalah. Hal ini dibuktikan dengan persentase ketercapaian indikator kemampuan berpikir tingkat tinggi mulai dari $\mathrm{C}_{4}$, $\mathrm{C}_{5}$ hingga $\mathrm{C}_{6}$ pada kelas eksperimen ynag nilainya lebih besar dibandingkan dnegan kelas kontrol yakni berturut-turut $77,69 \%, 66,47 \%$, dan $62,06 \%$. Sedangkan kelas kontrol berturut-turut $62 \%, 55,71 \%$, dan $42,86 \%$. Hal ini menunjukkan bahwa penerapan PBL dengan scaffolding prosedural dapat mempengaruhi kemampuan berpikir tingkat tinggi.

Lebih lanjut Pucangan dkk. (2018) mengemukakan bahwa pemberian scaffolding konseptual dalam problem based learning (PBL) mempengaruhi kemampuan pemecahan masalah siswa yang meningkat dibandingkan dengan sebelumnya. Penggunaan scaffolding konseptual berupa peta konsep juga dapat membantu siswa menganalisis data, menarik kesimpulan, dan memecahkan masalah selama melakukan kegiatan eksperimen dengan lebih baik. dengan adanya scaffolding berupa peta konsep, mempersempit informasi yang ditemukan dan memudahkan siswa memilih konepmateri yang 
digunakan untuk memecahkan masalah yang diberikan.

Disamping dengan memberikan scaffolding selama aktivitas belajar berlangsung, memilih masalah yang tepat untuk melatih siswa dalam mengasah kemampuan berpikir tingkat tinggi yang dimilikinyapun perlu dilakukan. Melatih siswa memecahkan jenis masalah bersifat kompleks secara kontinnu akan membiasakan siswa. Jenis masalah yang dapat dipilih diantaranya story, decision making, troubleshooting, strategic performance, policy analysis, dan design. Lestari (2019) melalui penelitiannya mengemukakan bahwa jenis masalah berupa strategic performance yang diintegrasikan dnegna PBL dapat meningkatkan kemampuan siswa dalam memecahkan masalah.

Berdasarkan berbagai hasil penelitian dan penelitian terkait sebelumnya, maka perlu dilakukan penelitian lebih lanjut mengenai pemberian scaffolding dalam bahan belajar berbasis masalah untuk meningkatkan kemampuan berpikir tingkat tinggi siswa. Hal ini bisa dilakukan dnegna mengembangkan bahan belajar berupa LKPD, e-LKPD hingga modul yang dilengkapi dengan scaffolding (dapat berbentuk alur, peta konsep, prosedural) berbasis jenis masalah bersifat kompleks yang dapat melatih ajarkan siswa untuk mampu memecahkan masalah hingga meningkatkan kemampuan berpikir tingkat tinggi.

\section{KESIMPULAN}

Berdasarkan pembahasan diatas, dapat disimpulkan bahwa pemberian bantuan berupa scaffolding yang diberikan guru pada saat proses pembelajaran sangat penting untuk dilakukan. Melalui bahan belajar berbasis jenis masalah tertentu yang dilengkapi dengan scaffolding dapat membantu siswa berlatih memecahkan jenis masalah baik yang sederhana hingga yang kompleks. Bahan belajar yang dapat dikembangkan dapat berupa LKPD maupun eLKPD. Selain itu, dengan memberikan bahan belajar yang dilengkapi dengan scaffolding yang tepat dapat membantu guru dalam memaksimalkan aktivitas belajar dalam upaya meningkatkan kemampuan berpikir tingkat tinggi terutama pada materi kimia yang bersifat abstrak dan kontekstual. Mengingat pentingnya hal ini untuk dilakukan, maka dibutuhkan pengembangan lebih lanjut terhadap bahan belajar berbasis jenis masalah yang bersifat kompleks dilengkapi dengan scaffolding untuk meningkatkan kemampuan berpikir tingkat tinggi siswa pada mata pelajaran kimia.

\section{DAFTAR PUSTAKA}

Belland, Brian R. (2017). Instructional Scaffolding In STEM Education Strategies And Efficacy Evidence. USA: Springer opent.

Brookhart, Susan M. (2010). How to Assess Higher Order Thinking skills In your Classroom. Virginia USA: Alexandria.

Haryati, T., Gusti, D. R., Hasibuan, M. H. E., \& Rusdi, M. (2020). Implementation of Scaffolding in Project Based Learning Model to Improve Skills of Science Process in Buffer Solution Material. JKPK (Jurnal Kimia dan Pendidikan Kimia), 5(2), 187-200.

Jonassen, David H. (2011). Learning to Solve Problems. San Fransisco: Pfeiffer.

Lestari, D. I. (2019). Analisis Keterlaksanaan Problem Based Learning Berbantuan Multimedia Pembelajaran Larutan Asam Basa Terhadap Keterampilan Memecahkan Masalah. Konfigurasi: Jurnal Pendidikan Kimia dan Terapan, 3(1), 1-7.

Nugroho, Arifin. (2018). HOTS (Higher Order Thinking Skills). Jakarta: Grasindo.

Pucangan, A. S. N. A., Handayanto, S. K., \& Wisodo, H. (2018). Pengaruh Scaffolding Konseptual dalam Problem Based Learning terhadap Kemampuan Pemecahan Masalah. Jurnal Pendidikan: Teori, Penelitian, dan Pengembangan, 3(10), 1314-1318.

Puspitaningsih, F., Wartono, W., \& Handayanto, S. K. (2018). Pengaruh PBL dengan Scaffolding Prosedural terhadap Kemampuan Berpikir Tingkat Tinggi Ditinjau dari Kemampuan Tinggi dan Rendah Siswa. Jurnal Pendidikan: Teori, Penelitian, dan Pengembangan, 3(7), 898902.

Sani, Ridwan A. (2019). Pembelajaran Berbasis HOTS (Higher Order Thinking Skills). Jakarta: TSmart.

Tiaradipa, S., Lestari, I., Effendi, M. H., \& Rusdi, M. (2020) The Development of 
Scaffolding in Inquiry-Based Learning to Improve Students' Science Process Skills in The Concept of Acid and Base Solution. JKPK (Jurnal Kimia dan Pendidikan Kimia), 5(2), 211-221.

Tindangen, Makrina. (2018). Inquiry BasedLearning Model To Improve Higher Order Thinking Skills. Canadian Center of Science And Education, 18(7), 39-46.

Wena, Made. (2011). Strategi Pembelajaran Inovatif Kontemporer Suatu Tinjauan Konseptual Operasional. Jakarta: bumi aksara.
Widiawati, L., Joyoatmojo, S., \& Sudiyanto, S. (2018). Higher Order Thinking Skills as Effect of Problem Based Learning in the 21 st Century Learning. International Journal of Multicultural and Multireligious Understanding, 5(3), 96105.

Yuriev, E., Naidu, S., Schembri, L. S., \& Short, J. L. (2017). Scaffolding the development of problem-solving skills in chemistry: guiding novice students out of dead ends and false starts. Chemistry Education Research and Practice, 18(3), 486-504. 